\title{
Feeding holy bodies: A study on the social meanings of a vegetarian diet to Seventh-day Adventist church pioneers
}

\begin{tabular}{|c|c|}
\hline \multicolumn{2}{|c|}{$\begin{array}{l}\text { Authors: } \\
\text { Ruben Sánchez Sábaté }^{1} \\
\text { Ramon Gelabert }{ }^{2} \\
\text { Yasna Badilla }^{3} \\
\text { Carlos Del Valle }\end{array}$} \\
\hline \multicolumn{2}{|c|}{$\begin{array}{l}\text { Affiliations: } \\
{ }^{1} \text { School of Education, Social } \\
\text { Sciences and Humanities, } \\
\text { Universidad de La Frontera, } \\
\text { Chile }\end{array}$} \\
\hline \multicolumn{2}{|c|}{$\begin{array}{l}{ }^{2} \text { Research Director, } \\
\text { Universidad Adventista } \\
\text { de Chile, Chile }\end{array}$} \\
\hline \multicolumn{2}{|c|}{$\begin{array}{l}{ }^{3} \text { Psychology Department, } \\
\text { Universdad de La Frontera, } \\
\text { Chile }\end{array}$} \\
\hline \multicolumn{2}{|c|}{$\begin{array}{l}\text { Corresponding author: } \\
\text { Ruben Sánchez Sabaté, } \\
\text { ruben.sanchez@ufrontera.cl }\end{array}$} \\
\hline $\begin{array}{l}\text { Dates: } \\
\text { Received: } 10 \mathrm{~J} \\
\text { Accepted: } 24 \\
\text { Published: } 10\end{array}$ & $\begin{array}{l}\text { une } 2015 \\
\text { Dec. } 2015 \\
\text { June } 2016\end{array}$ \\
\hline \multicolumn{2}{|c|}{$\begin{array}{l}\text { How to cite this article: } \\
\text { Sanchez, R., Gelabert, R., } \\
\text { Badilla, Y., Del Valle, C., 2016, } \\
\text { 'Feeding holy bodies: A study } \\
\text { on the social meanings of a } \\
\text { vegetarian diet to Seventh- } \\
\text { day Adventist church } \\
\text { pioneers', HTS Teologiese } \\
\text { Studies/Theological Studies } \\
72(3) \text {, a3080. http://dx.doi. } \\
\text { org/10.4102/hts.v72i3.3080 }\end{array}$} \\
\hline \multicolumn{2}{|c|}{$\begin{array}{l}\text { Copyright: } \\
\text { (c) 2016. The Authors. } \\
\text { Licensee: AOSIS. This work } \\
\text { is licensed under the } \\
\text { Creative Commons } \\
\text { Attribution License. }\end{array}$} \\
\hline \multicolumn{2}{|l|}{ Read online: } \\
\hline 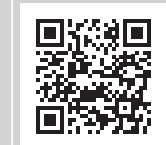 & $\begin{array}{l}\text { Scan this QR } \\
\text { code with your } \\
\text { smart phone or } \\
\text { mobile device } \\
\text { to read online. }\end{array}$ \\
\hline
\end{tabular}

Ten years ago National Geographic magazine reported that the Loma Linda Seventh-day Adventist population is one of the communities in the world that lives longer and with a higher quality of life thanks in part to the biological benefits of a vegetarian diet. Along with National Geographic, other media outlets have reported since then that the Adventist religious community considers a plant-based diet a very important factor for a healthy lifestyle. Adventists have been promoting this type of diet worldwide for more than 150 years. This article is an attempt to understand from a social-scientific perspective the origin of the importance they lend to diet and see whether this helps explain why approximately 150 years after the founding of the church, diet remains crucial for Adventists around the world. The conclusion proposed is that Adventists understood the adoption of a plant-based diet as a special divine instruction in order to nourish their new identity as a special people differentiated from the rest of society. This was possible through a desecularisation of diet that placed food in the moral category of the Adventist belief system.

\section{Introduction}

In 2005, National Geographic published a piece on longevity, reporting on three different communities in the world that live longer and enjoy a better quality of life than usual (Bueltner 2005b). Among them was the Seventh-day Adventist community in Loma Linda, CA, USA. The article aimed to reveal the secrets for longevity of these three disparate groups. In the case of Adventists, one such secret was a plant-based diet. Since then, numerous media outlets like CNN (Gupta 2015) and books like The Blue Zones have pointed to the practice of a plant-based diet as an important factor in keeping Loma Linda Adventists healthy. Based on this example, it has been easy for authors and journalists alike to recommend readers aspiring to live longer and better to adopt a plant-based diet as far as possible.

What mass media reporting on Loma Linda Adventists has also shown is that not only a vegetarian diet is important to their health, as scientific research has demonstrated (Fraser 2003), but also that Adventists lend great importance to what they eat. In other words, Loma Linda Adventists understand and perceive a vegetarian diet as a basic aspect of their lifestyle not easily influenced by the general US market food culture.

The Adventist church has valued diet since its foundation in 1863. Its pioneers and founders considered a healthy diet to the point that during the second half of the 19th century they invented one of the most popular breakfasts in the US and Europe: flakes and granola (Bueltner 2005a). Adventist Dr John Harvey Kellogg conceived of these in his effort to provide healthy food alternatives to his patients.

Nowadays the prevalence of vegetarianism among American Adventists is remarkable. Whilst the overall percentage of American adults who consider themselves vegetarians or vegans is $8 \%$ (Gallup 2012), longitudinal studies have found that 50\% of American Adventists are vegan, vegetarian or almost vegetarian (eat meat less than once a week) (Fraser 2003:5). At the organisational level, the Seventh-day Adventist church promotes a plant-based diet and serves only vegetarian meals at official church events.

What follows is an interdisciplinary attempt to explore the relationship early Adventists had with diet in order to better understand the origin of the importance they lend to diet and see whether it helps explain why approximately 150 years after the founding of the church, diet is still crucial for Adventists around the world. 


\section{Theoretical framework}

Food choice is a complex matter that has been analysed from different perspectives. Jane Ogden collected the main research on the issue and presented the main factors and motivations that condition food selection (Ogden 2010:32). There are physical factors (like geography and economy), social factors (like religion and class) and physiological factors (like allergies) that, combined with any of the nine psychological motivations conceptualised as choice influencers (sensory appeal, weight control and mood regulation, among others), explain and may predict an individual's food choice.

Ogden affirmed that, from a psychological perspective, scientific literature points to three core theoretical approaches used to study food choice: (1) the developmental model, which 'emphasises the importance of learning and experience and focuses on the development of food preferences in childhood' (Ogden 2010:32); (2) the cognitive model, which 'focuses on an individual's cognitions' (Ogden 2010:43) in the process of choosing food; and (3) the psychophysiological model, which 'focuses on hunger and satiety' (Ogden 2010:49). The complementary use of these three models, however, is insufficient to understand the complexity of food choice because:

these theoretical frameworks, with their focus on the individual, minimize the complex meanings surrounding food and body shape and size. Food choice takes place within a set of social meanings concerning individual foods, meals as a social and cultural experience ... (Ogden 2010:62)

The need to include theoretical approaches that take into account social, cultural and religious phenomena in the study of food selection is reinforced first by general anthropological insights and second by the scientific acknowledgement that nutrition is also a social construction. Regarding the former, when related to health and food, we can refer to Nola Pender's health promotion model (Pender \& Murdaugh 2015), Bandura's social cognitive theory (Jáuregui Reina \& Suarez Chavarro 2004), and value expectation theory (Feather \& Davenport 1982). Regarding the latter, we can point to the communicative strategies and aspects in play in the construction of nutritional habits (Coe 1998; Bateson 1998; Bateson \& Winkin 1990; Del Valle \& Matus 2007), and to the need to understand nutrition as a social construction generated and reproduced by social ties (Pichon-Riviere 1985; Kamieneski \& Brown et al. 2000; Holland \& Breitbart 1998; Carreño \& Vyhmeister et al. 2006).

The study of food as a social practice with cultural and religious significations dates back to the 19th century at least. However, the theoretical foundations on the topic were published during the second half of the 20th century. Anthropologists such as Mary Douglas, Margaret Mead and Claude Lévi-Strauss, sociologists like Pierre Bourdieu, and semioticians such as Roland Barthes and Jean Soler have framed the study of food as a social product rich in cultural signification. What follows is a selection of the foundational theoretical insights that make possible a sociocultural approach to the study of early Adventists' food choices.

\section{Food is also culture}

In his essay 'The culinary triangle', Lévi-Strauss pointed to the biocultural nature of food, noting that when we cook we culturally transform the raw. Boiling for instance is a double mediation of nature (water) and culture (the receptacle that contains both water and food) (Lévi-Strauss 1997:29) LéviStrauss added that 'cooking is not located entirely on the side of culture', it adapts 'itself to the exigencies of the body'. Therefore 'cooking represents their necessary articulation' (Lévi-Strauss 1997:33). This cultural transformation of food is for Lévi-Strauss a universal human characteristic at the same fundamental level as language (Lévi-Strauss 1997:28).

Barthes took this observation further to the point of equating food to language (Barthes 1979:167-168). In his essay 'Toward a psychology of contemporary food consumption', he affirmed that food is a sign in every society (Barthes 1979:168). Food can define, give or recognise the meaning of one person in the tribe: for example, the chief gets the head of an animal or the best food. Such semiotic processes can occur only when there is a previous differentiation of foods (Soler 1979:128). As Soler noted, in the same way that early Christians rejected the Sabbath to differentiate themselves from the Jews, Saint Peter's vision 'in which the [already present Jewish] distinction between clean and unclean foods was abolished had thus implied the abolition of the distinction between Jews and non-Jews' (Soler 1979:137).

If food carries distinctions and is therefore a sign, it becomes a means to express ideas and values, if not a reflection of the eater's identity. Barthes argued that the way we talk about food has a direct connection with the beliefs and practices that make our lives. 'Modern nutritional science', Barthes affirmed, 'is not bound to any moral values such as asceticism, wisdom or purity, but on the contrary, to values of power. The energy furnished by a consciously worked out diet is mythically directed, it seems, toward an adaptation of man into the modern world' (Barthes 1979:171). For Barthes the relationship between food and culture went as deep as to say that what we eat could be elevated to a category of the world (Barthes 1979:167), as in the case of McGuire sisters' American hit, 'Sugartime!'.

All this supports Marguerite Perrot's idea that changing food habits is in fact changing tastes, which in turn means ideas (Barthes 1979:167).

\section{Methodology}

In our attempt to understand why early Adventists (any time between 1863 and 1914) adopted a vegetarian diet, and most importantly, why 150 years after the church's founding a plant-based diet is still preferred and promoted across the globe, we have built an explanatory case study with primary and secondary sources and followed exploratory and analytical methods with a qualitative approach.

As primary sources we have used what the Adventist community considered and still considers literature directly 
inspired by God to her messenger or prophetess, Ellen G. White. As secondary sources we have worked with the two most important scholarly books on White, Adventism and the health reform that took place in the US during the 19th century: first, a book titled Prophetess of health: A study of Ellen G. White, written by historian and former Adventist, Ronald L. Numbers (1st ed. 1976, 3nd ed. 2008). This is a thoroughly documented work of social history which showed the extent to which White's writings are indebted to the literature of the time. The second source is a book that should be understood as the quasi-official Adventist response to Numbers's book. Commissioned to Adventist theologian Herbert E. Douglass by the The Ellen G. White State Inc., the Seventh-day Adventist organisation in charge of the custody and dissemination of her writings, Messenger of the Lord (1998) deals with many issues raised by Numbers, but mainly with an Adventist audience in mind.

By agreeing with Ogden that understanding food choices requires a variety of theories and methods, we acknowledge that any answer we may give to the proposed research question will be limited due to the lack of subjects alive to interview. It is impossible to use developmental, cognitive or psychophysiological models when studying subjects of a foreign time and place, unless we were to find and study written primary sources of the time describing the subjects of that era on many levels. But this would be another research project on its own. Therefore, due to the nature of our sources and our expertise, we have looked for the social, cultural and religious meanings in order to find the immaterial reality that explains the Adventist preference for a vegetarian diet. By immaterial reality we mean beliefs, interpretations, reasoning, myths and meanings that form social identities, shape cultural experiences and construct religious experiences. In other words, we have tried to find out how early Adventists' understandings of food and diet were incorporated into their cultural symbolic system in order to establish such a 'powerful, pervasive and longlasting mood and motivation' (Geertz 1973:90) towards a plant-based diet. What follows then is a limited reconstruction of the facts and their context regarding the early Adventists choice of a vegetarian diet and an analysis with the help of different social theories.

\section{The case of the early Seventh-day Adventist community}

Traditional and current forms of Christian Protestantism say hardly anything about diet and leave it to the dominant culture in every location. Food is not a religious sign in these cases and thus any cultural meanings food may have come from the dominant culture in which the religious community is embedded. Adventism, however, stands out as a notable exception. Very early on, Adventists gave diet an important role, making it part of their health message which was understood as the 'right arm' of the gospel:

The gospel of health has able advocates, but their work has been made very hard because so many ministers, presidents of conferences, and others in positions of influence have failed to give the question of health reform its proper attention. They have not recognized it in its relation to the work of the message as the right arm of the body. Whilst very little respect has been shown to this department by many of the people, and by some of the ministers, the Lord has shown His regard for it by giving it abundant prosperity. When properly conducted, the health work is an entering wedge, making a way for other truths to reach the heart. When the third angel's message is received in its fullness, health reform will be given its place in the councils of the conference, in the work of the church, in the home, at the table, and in all the household arrangements. Then the right arm will serve and protect the body. (White 2002)

And as stated at the beginning of this article, a vegetarian diet remains a hallmark of Adventism. Other churches like Jehovah's Witnesses and The Church of Jesus Christ of Latter-day Saints, which were also born in the 19th century and similarly to Adventists, encourage their members to abstain from alcohol, tobacco and caffeine, did not give food such a predominant role at that time, and still do not today.

The Seventh-day Adventist church was officially founded in 1863, at a time when the US was in desperate need of a health reform. Historian Ronald Numbers explained that:

America in the early nineteenth century was a sick and dirty nation' with such useless medical knowledge that by 1860 it was said that 'if the whole materia medica, as now used, could be sunk to the bottom of the sea, it would be all the better for mankind - and all the worse for the fishes. (Numbers 2008:95, 96)

This situation prompted a growing interest in literature on preventive measures and health. Books arrived from Scotland condemning popular dietary and therapeutic abuses. Boston and Philadelphia saw the birth of health journals and the publication of health books with a common theme: 'the importance of a proper (often meatless) diet' and other lifestyle advice such as temperance (Numbers 2008:96). Health crusades started as early as the 1830s, with reverends like William Metcalfe, who authored the first American tract on vegetarianism and set up the vegetarian Bible Christian Church (Numbers 2008:96). Sylvester Graham, another reverend and health reformer, emphasised the benefits of a vegetarian diet in his programs on temperance, and also in his lectures on 'the Science of human life' at the Franklin Institute (Numbers 2008:97).

It was in this context that in 1866 Adventism's main figure, Ellen White, urged the Adventist church to build the Western Health Reform Institute, a hospital-like centre in which only natural means like a 'strictly healthful diet, consisting of vegetables, grains and fruits' would be used to cure; and to publish the monthly journal Health Reformer, which of course included dietary advice (Numbers 2008: $157,162)$. 


\section{Adventism's holy writings}

Ellen White lived from 1827 until 1915. She was one of the founders and the main leader of the at that time so-called Adventist movement. Her influence on the founding of the Seventh-day Adventist Church and its early steps was crucial. She wrote a large number of books, and, according to the Seventh-day Adventist church, she is the most translated woman in history. Her writings on theology and lifestyle are available all over the world in several languages.

White claimed to receive 'visions from God'. Even though she rejected being regarded as a prophet, she said of herself that she was a 'lesser light' pointing to 'the greater light' (White 1999), the Bible, meaning that the community of believers could find in her guidance for the study and understanding of the Bible. Her writings on health, considered by the Adventists equally inspired by God as those on beliefs, gave Adventists a set of rules and advice on dietary habits among other health-related recommendations.

It is a common fact that the birth of new religious movements comes with new scriptures. As Graham pointed out, this is a question of legitimacy: it was necessary for religious movements to have scriptures (Graham 1993:52). The elevation of White's writings to 'scriptures' is an action performed by the religious community. In other words, the sacrality of a book or a set of writings depends on the response of a group of people to it (Graham 1993:5). The power of her writings rests on the fact that Adventists take them as inspired by God. It is thus a relational phenomenon that puts White's writings into the category of sacred among Adventists (Graham 1993:6). Because White's writings are considered among Adventists as 'divine knowledge or decrees' (Graham 1993:50), conversations between Adventists tend to include expressions like 'Ellen White says this or recommends that' in an attempt to invest one's own arguments with authority and authenticity.

In the case of the 19th century Adventists, when many different and often contradictory ideas about health were circulating across the U.S. (Numbers 2008), the legitimacy for their diet was based entirely on White's writings. Nowadays, Adventists also look for legitimation in science in an effort to base their dietary postulates on the authoritative language of the dominant secular culture. This is why Loma Linda University, an Adventist education and research institution close to Los Angeles, CA, leads the research on vegetarian nutrition.

The importance of White's writings among Adventists can be further illuminated by Stanley Tambiah's anthropological study on 'The Magical Power of Words' (Tambiah 1985:17-38), which showed that religions have always attributed a special creative power to words. Thus:

the Parsi religion states that in the battle between good and evil it was through the spoken word that chaos was transformed into cosmos; ancient Egypt believed in a God of the Word; the Semites and the Sumerians have held that the world and its objects were created by the word of God; and the Greek doctrine of logos postulated that the soul or essence of things resided in their names. (Tambiah 1985:27)

Tambiah noted that religions characterise sacred language with certain values and roles that could be summarised like this: (1) The divine entity creates the world with words; (2) humans continue this process through speech; and (3) language becomes an entity able to act in its own right (Tambiah 1985:27-28).

Using Tambiah's insights to look at the Adventist case, it can be understood how White's writings created a new world of meaning in which diet was a crucial part. Her words inspire actions in all spheres of life even today, the most noticeable of which are food selection. This new cultural world created where diet acquired a significant role was not so much made possible through new names or new words for already existing foods, diets and eating practices. Rather, this process was possible thanks to a change in the category of food. One early Adventist clearly illustrated this phenomenon when talking about the health principles proposed by White:

As mere physiological and hygienic truths, they might be studied by some at their leisure, and by others laid aside as of little consequence; but when placed on a level with the great truths [...] by the sanction and authority of God's Spirit, [...] then it comes to us as an essential part of present truth, to be received with the blessing of God, or rejected at our peril. (Douglass 1998:217)

In scientific language, this new world placed diet in the moral sphere of the Adventist community.

The construction of new worlds through language and symbols has been very well studied by Berger and Luckmann (Berger \& Luckmann 1990; Berger 1990). They referred to religion, science and others as the most important symbolic systems that humanity has developed in constructing representations of the world. This is a social process, they affirmed, in three basic processes. (1) Externalisation: the subject externalises his inner world; (2) Objectification: the externalisation of the subject becomes accessible to other subjects; and (3) Internalisation: the subject internalises whatever object is available. It is in this threefold dialectical process that social worlds are constructed. From this perspective we can say that Ellen White took objects regarding dietary patterns already available in her historical context and objectified them in her writings. It was in this process of objectification that a new canon of sanctioned dietary patterns was established for Adventists, who in turn internalised it as the Word of God. As reported by the most comprehensive scholarly study of Adventism to date:

at an Adventist home in Otsego, Michigan, Ellen White received a revelation from God that stressed the need for health reform [...] Ellen White clearly understood the laws of health to be of divine origin [...] The Otsego vision marked the point at which Seventh-day Adventists began to accept the principles of health reform in significant numbers. (Bull \& Lockhart 2007:164-165) 
This new Adventist understanding of diet as something prescribed by God can also be explained as the product of a desecularisation process. If secularisation is the transfer of things, functions, meanings and so on from the religious sphere to the secular sphere (Casanova 1994:13), in the Adventist case dietary habits were reclaimed back from the secular and installed in the religious sphere.

\section{New diet, a ritual for a new identity}

Such internalisation of new divine decrees meant the incorporation of a new set of invisible values, ideas and internal dispositions for the Adventist community. Keeping Perrot in mind, these new beliefs on diet were made visible, materialised, by changes in daily eating choices. Since a new set of beliefs with a new set of practices means a new subject, it may be said that the adoption of a new dietary pattern was in fact the acquisition of a new social category.

If we take acquiring new dietary patterns as a ritual activity of social category change in Victor Turner's understanding (Turner 1967:93-94), that is, a three phase ritual consisting of, firstly, separation, in which the individual is detached from their former social status; secondly, transition, in which the subject finds herself in a social limbo, and finally, incorporation, in which the person acquires her new social status, we can see the process for new converts adopting a new diet as a ritual extended in time where they go from a non-Adventist diet to an Adventist one. The time they spend getting used to the new dietary patterns is the transition, the liminal period in which these subjects find themselves in a dietary limbo, the eating practices of which do not belong to their former social world or to the Adventist one. In other words, it is in the process of disciplining themselves into new foods and flavours and into new ways of cooking that they build their new identity in opposition to the rest of the society meal by meal.

\section{A special diet for a special people}

Soler's semiotical analysis of food in the Bible illuminates further the connections between food and the Adventist construction of a new social category, of a new people. Building upon Lévi-Strauss' structuralist analysis of food in society, Soler affirmed that 'by bringing to light the logic that informs [dietary] choices [...] we can outline the specific characteristics of a society' (Soler 1979:126). With this in mind, Soler takes the reader through the dietary texts and laws found in the Bible and uncovers a pattern in which dietary rules coincide with intended distinctions among peoples. Some examples to support this reading given by Soler are: (1) God's covenant with Noah. This is universal, for all humanity and thus no distinction is made among foods. There are no pure or impure animals. Everything edible is blessed by God in the same way as the promise of never again flooding the whole earth; (2) God's covenant with Moses. This only concerns one people, the Hebrews. Since a new distinction is made among peoples, new dietary laws are given. Animals are now classified as pure or impure, in the same way that humanity can now be distinguished between the holy people of Israel and the unholy rest; (3) Jesus' new covenant. In Mark 7:19 Jesus declared all foods clean, abolishing the distinctions between Jews, Romans, Samaritans ... and making Christianity universal, i.e. all peoples become one in Christ. From all these examples it is seen that food can be understood as a metaphor for humanity.

This very same logic uncovered by Soler is present in the Seventh-day Adventist church. Adventist pioneers regarded themselves as the 'spiritual Israel' (White 1997), heirs of the people of Israel's salvific mission. They understood they were a chosen people with a special mission. Following a historic interpretation of the Book of Revelation, they identified themselves with the 'remnant' (Pfandl 2008). In this way White warned against the possibility of losing the special truths they believed God had entrusted to them:

The enemy of the souls has sought to bring in the supposition that a great reformation was to take place among Seventh-day Adventists, and that this reformation would consist in giving up the doctrines which stand as pillars of our faith, and engaging in a new process of reorganization. Were this reformation to take place, what would result? The principles of truth that God in His wisdom has given to the remnant church would be discarded. (White 2006:204)

The Adventist self-description as the 'remnant' has endured until today. Not only is it present in the baptismal vows, 'Do you accept and believe that the Seventh-day Adventist Church is the remnant church of Bible prophecy ...' (Seventhday Adventist Church 2010:47), but also a survey conducted for the General Conference of the Seventh-day Adventist Church revealed that $90 \%$ of Adventists believe that '[t]he Adventist Church has a special mission to proclaim God's last message to the world' (Institute of Church Ministry 2002).

A special people needed a special diet. Thus, White (1946) wrote:

Is it not time that all should aim to dispense with flesh foods? How can those who are seeking to become pure, refined, and holy, that they may have the companionship of heavenly angels, continue to use as food anything that has so harmful an effect on soul and body? (p. 380)

The idea that holy people need a holy diet is also present in the Adventist baptismal vows:

Do you believe that your body is the temple of the Holy Spirit and will you honour God by caring for it, avoiding the use of that which is harmful, and abstaining from all unclean foods...? (Seventh-day Adventist Church 2010:47)

These previous quotes also show the connection early Adventists had between the traditional Biblical and theological concept of holiness with one of the greatest 
concerns of their time: learning a healthy lifestyle. In this regard, White wrote:

It is for their own good that the Lord counsels the Remnant Church to discard the use of flesh meats, tea, and coffee, and other harmful foods. There are plenty of other things on which we can subsist that are wholesome and good. (White 1946:381)

The theme that runs underneath these passages is that Adventists did not strive to adopt a vegetarian diet simply for health's sake. On the contrary, it was because they believed they were the 'remnant', a 'chosen people', a 'holy people' that they had to be healthy and therefore avoid meat. The drive to adopt a plant-based diet was mainly in their identity as a people. Being healthy was not an end in itself as it likely was for many of their contemporaries. Being healthy was a means to become the new people, different from the rest, as they aspired to be. Healthy is a state of being, not an identity. 'The remnant' is a myth, a vision, a desire, a new way of inhabiting this world. Adventists created a new identity in the same way Moses took the Israelites out of Egypt to birth a new civilisation: by providing a new classification of foods. As Soler (1979) explained:

... the cut is the origin of differentiation, and differentiation is the prerequisite of signification. Dietary prohibitions are indeed a means of cutting a people off from others ... (p. 129)

The only difference though is that, whilst for Moses it was about pure and impure, clean and unclean foods, for Adventists, strongly influenced by a society preoccupied with health, it was about healthy and unhealthy foods.

\section{Diet as symbol}

If a new diet is a means to a new identity, it is because diet has a series of meanings attached that fits into the new belief system. In our attempt to decode the meanings a plant-based diet had for early Adventists, we will follow Victor Turner's anthropological approach to the meaning of a symbol. Turner proposes distinguishing three levels of meaning (Turner 1965:82). The first is the exegetical meaning, which derives from whatever the subjects performing the action may say about it; the second is the operational meaning, which equates 'the meaning with its use', i.e. what the subjects do with the practice studied; and finally the positional meaning, which has to do with the position the studied practice occupies in the whole symbolic structure of the community's culture. Thus, in the case of Adventists we will explore (1) the exegetical meaning, in which we will showcase how the Ellen White's Adventist interpretation understands diet; (2) the operational meaning, in which we will present what Adventists did with dietary patterns; and (3) the positional meaning, in which the exegetical meaning will be placed in the Adventist context.

\section{Exegetical meaning}

As exegetical meaning, we can see that food is full of symbolism in the Adventist community. In Ellen White's time a vegetarian diet was a sign for the Adventists that
God had revealed to them a special truth of what they considered the Everlasting Gospel (Douglass 1998:214). Adventists believed they had to preach what they called 'the present truth' and a vegetarian diet was a very important part of that (Douglass 1998:215).

A vegetarian diet also contained a holistic understanding of the human being (Douglass 1998:193). Adventists broke with the Christian tradition of separating mind and body. Therefore, they believed that 'a healthy mind and body directly affects one's morals and one's ability to discern truth' (Douglass 1998:210). Keeping in mind the current anthropological understanding that it is foolish to believe that we have full agency (Latour 2003), a vegetarian diet reminded Adventists that agency depends on natural factors as well.

Finally, a vegetarian diet was and is a way to retell Adventists' believed history of the planet Earth. By eating a plant-based diet, Adventists were remembering God's original plan for humanity every day (Garden of Eden) and his promise of restoration (Second Coming) (Douglass 1998:193). Since before original sin God provided only a plant-based diet and Adventists believe diet will be the same in heaven, when eating, Adventists remember where they come from, who they were/are and where they were/are going.

\section{Operational meaning}

Adventists did at least four things with the practice of eating vegetarian. First, they demonstrated their faith in God (Douglass 1998:197). By doing this, Adventists were signifying to one another and to the wider society their degree of commitment with the Adventist message. Second, they were joining the spiritual and the physical on the practical, daily level of the average person (Douglass 1998:215), a demonstration of their holistic understanding of human nature.

Third, Adventists accomplished their required process of 'sanctification', a central Adventist tenet. Adventist theology understands sanctification first as a new relationship with God that confers on the believer a new status of having been set apart from the rest of society (Review and Herald Publishing Association 2000:295); and second, 'as a moral growth in goodness. [...] Thus, the sanctified life involves a continual quest to learn what pleases God in all the circumstances of life (Eph 5:8, 9; 1 Th 4:1)' (Review and Herald Publishing Association 2000:298). Of course, food choices were no exception. Adventist pioneer D.T. Bourdeau wrote in his book Sanctification or living Holiness, the following regarding the 'sanctification of the body':

Sanctification brings the appetites within their proper limits [...] Whether we eat or drink, or whatever we do, we should do all to the glory of God. [...] In view of these principles what shall we conclude concerning those parents who are almost constantly humoring their children in satisfying their appetites with so many niceties which injure the health and undermine the constitution? Are they not guilty of creating in them unsanctified appetites? (Bourdeau 1864:43-44) 
In this sanctification process, following a healthy diet to keep a healthy body is crucial because, as can be read in the many pages written by Ellen White linking dietary habits and morality (White 1945), the ability to act morally is connected to one's health:

Let none who profess godliness regard with indifference the health of the body, and flatter themselves that intemperance is no sin, and will not affect their spirituality. A close sympathy exists between the physical and the moral nature. (White 1946:43)

Drawing from Pierre Bourdieu's concept of habitus, we can say that what Adventism calls sanctification is the process of acquiring dispositions that would generate practices and perceptions in keeping with God's commandments. Since changing diet is not an easy process and sanctification is for Adventists a lifelong process, we can conclude that with diet they acquired a new Adventist habitus (Douglass 1998:193, 196-197).

And fourthly, Adventists also used their knowledge about a healthy diet to evangelise. As White wrote:

$[H]$ ealth reform is to be the bridge over which the gospel will meet people where they are, the door through which the truth for this time is to find entrance to many homes. (Douglass 1998:215)

Food is in these cases a medium to communicate values and ideas, and a way to reinforce a sense of belonging to a certain interpretation of the world.

\section{Positional meaning}

Adventist theology is based on the Great Controversy, in which God must vindicate his real character after being falsely accused by Satan. Therefore, God wants to expose the nature of rebellion, whilst at the same time restore the creation. In this context, human beings were created with the freedom to choose between God's plan or Satan's plan. Hence, humans can be irresponsible but never 'unresponsible' (Douglass 1998:193). In this context, a vegetarian diet was understood by early Adventists not only as way to restore or improve God's image in them, but also as a natural proof that God's plan for humanity is only good (Douglass 1998:191). In other words, when changing dietary patterns Adventists felt better; they saw a vindication of God in themselves.

This vindication can be further illuminated if we consider it a result of material mediation of the divine. Following Luhmann's understanding of 'religio', which is the linking of what cannot be designated to what can be (Luhmann n.d.:556), in the Adventist context, diet was understood as a way to connect our daily materiality with God, or in Luhmann's terms, with the immaterial 'secret' (Luhmann n.d.:559). A vegetarian diet revealed to them a greater part of the secret, i.e. God. Therefore if mediation is making the invisible visible (Zito 2008b, 2008a:77), diet made early Adventists' understanding of God's love so visible that they could feel and experience it.

\section{Conclusion}

Understanding and predicting food choices requires the complementary use of theories and methods that take into account a series of individual and social factors. In our attempt to answer why it is that Adventist pioneers had such a high regard for a vegetarian diet, we have considered historical, social, cultural and religious factors obtained from primary and secondary sources. Our main conclusion is that Adventists understood the adoption of a plant-based diet as special divine advice or an instruction to nourish their new identity as a special people differentiated from the rest of society.

The birth of the Adventist church occurred in the midst of a national interest in learning how to live healthier. Adventists joined in the production of health literature and health centres motivated by what they believed to be holy writings specially inspired by God to Adventism's prophet, Ellen White. Adventist scriptures were a fundamental instrument in the construction of a new social world where dietary patterns undergo a desecularisation process and are placed in the moral system of the Adventist community. Food then becomes a moral category and can therefore neither be easily negotiated nor colonised by the dominant secular culture.

The transition from a common diet to the divinely inspired healthy one meant for Adventists a change in social terms. The period of slowly incorporating a new diet can be understood as a liminal period until the new social category is achieved. Based on a historic interpretation of the Book of Revelation, Adventists named this new identity 'the remnant' and defined it as a special people called by God out of society. It was this understanding of being 'the remnant' that drove early Adventists to strive to be as healthy as possible. Health was not an end in itself, but a means. A vegetarian diet, then, was God's instructed means to be healthy.

From a symbolic perspective, diet was a medium to convey a series of meanings for early Adventists. It was a language to communicate amongst themselves, with the divine and with those who were not yet Adventists. Amongst themselves: A vegetarian diet gave Adventists an important role in their cosmogony. In other words, food placed them in a narrative filled with values retold through the ritual of eating. In this sense, nowadays dietary patterns are for Adventists also a way to remember their pioneers' identity and their mission in this world. With the divine: Diet also had an important meaning in the acquisition of an Adventist habitus, what Adventists theologically called 'sanctification'. In keeping God's commandments, they were being faithful to God. With non-Adventists: a vegetarian diet was a tool to open doors to evangelise, a way to take the gospel to the people.

For all this we can say that some distinctive Adventist traits when compared with the majority of Protestants are symbolically inscribed in food, which is simultaneously ingested, incorporated and embodied. If we take into account the fact that Adventists understand their bodies as the 
temple of the Holy Spirit', i.e. the body as a religious and not secular entity, it becomes easier to understand why they had to choose their diet so carefully: because they were feeding their holy bodies.

\section{Acknowledgements Competing interests}

The authors declare that they have no financial or personal relationships which may have inappropriately influenced them in writing this article.

\section{Authors' contributions}

R.S. (Universidad de La Frontera) was the project leader, R.G. (Universidad Adventista de Chile) contributed with acquisition of data and critical revision of the draft, Y. B. (Universidad de La Frontera) contributed with research for the theoretical framework and interpretation of the data, and C. del V. (Universidad de La Frontera) contributed with research for the theoretical framework and critical revision of the draft.

\section{References}

Barthes, R., 1979, 'Toward a psychosociology of contemporary food consumption', in R. Forster, (ed.), Food and drink in history: selections from the Annales, économies, sociétes, civilisations, vol. 5, John Hopkins University Press, Baltimore.

Bateson, G., 1998, Pasos hacia una ecología de la mente, Lohlé-Lumen, Buenos Aires. Bateson, G. \& Winkin, Y., 1990, La nueva comunicación, Kairós, Barcelona.

Berger, P.L., 1990, The sacred canopy: Elements of a sociological theory of religion, Anchor Books, New York.

Berger, P.L. \& Luckmann, T., 1990, The social construction of reality: A treatise in the sociology of knowledge, Anchor Books, New York.

Bourdeau, D.T., 1864, Sanctification or, Living Holiness, Steam Press of the Seventhday Adventist Publishing Association, Battle Creek, viewed 04 November 2015, from http://text.egwwritings.org/publication.php?pubtype=Book\&bookCode=SL H\&lang=en\&section=all\&pagenumber $=2$

Bueltner, D., 2005a, 'Longevity, the secrets of long life, learn more', Nationa Geographic Magazine, viewed 18 May 2015, http://ngm.nationalgeographic. com/ngm/0511/feature1/learn.html

Bueltner, D., 2005b, 'Longevity, the secrets of long life' National Geographic Magazine viewed 18 May 2015, from http://zotero://attachment/362/

Bull, M. \& Lockhart, K., 2007, Seeking a sanctuary: Seventh-day Adventism and the American dream, 2nd edn., Indiana University Press, Bloomington.

Carreño, J., Vyhmeister, G., Grau, L., Ivanovic, D., 2006, 'A health promotion programme in Adventist and non-Adventist women based on Pender's model: A pilot study', Public Health 120(4), pp. 346-355.

Casanova, J., 1994, Public religions in the modern world, The University of Chicago Press, Chicago.

Coe, G.A., 1998, 'Comunicación y promoción de la salud', Chasqui. Revista Latinoamericana de Comunicación 63.

Del Valle, Carlos F. \& Matus, E., 2007, Comunicación para la salud: necesidad de una praxis educomunicativa participativa en campañas de prevención y promoción de la salud. En Rodríguez Monarca, María Claudia, ed. Sociedad y Cultura: Reflexiones Transdisciplinarias. Valdivia, Chile: Universidad de La Frontera - MECESUP Universidad Austral de Chile, pp. 43-48.

Douglass, H.E., 1998, Messenger of the Lord: The prophetic ministry of Ellen G. White, viewed 01 May 2011, from http://www.whiteestate.org/books/mol/ motl.pdf

Feather, N.T. \& Davenport, P.R., 1982, 'Desempleo y sentimiento depresivo: Un análisis motivacional y atributivo' Estudios de Psicología 3(12), pp. 63-81.

Fraser, G.E., 2003, Diet, life expectancy, and chronic disease: studies of Seventh-Day Adventists and other vegetarians, Oxford University Press, Oxford.

Gallup, 2012, In U.S., 5\% consider themselves vegetarians, viewed 09 June 2015, from http://www.gallup.com/poll/156215/consider-themselves-vegetarians.aspx
Geertz, C., 1973, The Interpretation of Cultures, Basic Books, Inc., Publishers, New York.

Graham, W., 1993, Beyond the written word: oral aspects of scripture in the history of religion, Cambridge [Cambridgeshire], Cambridge University Press, New York.

Gupta, S., 2015, 'The art of aging', CNN Video, viewed 25 April 2015, from http:// edition.cnn.com/videos/world/2015/02/20/spc-vital-signs-art-of-aging-a.cnn

Holland, W. \& Breitbart, W. (eds.), 1998, 'Social ties and cancer', in Psycho-oncology, Oxford University Press, New York.

Institute of Church Ministry, 2002, 'report prepared for the Strategic Planning Commission, General Conference of Seventh-day Adventists.

Jáuregui Reina, C.A. \& Suarez Chavarro, P., 2004, Promoción de la salud y prevención de la enfermedad: enfoque en salud familiar, Editorial Médica Panamericana, Bogotá.

Kamieneski, R, Brown, C.M., Mitchell, C., Perrin, K.M \& Dindial, K. 2000, 'Health benefits achieved through the Seventh-Day Adventist Wellness Challenge Program', Alternative therapies in health and medicine 6(6), pp. 65-69.

Latour, B., 2003, The promises of constructivism, viewed 06 November 2015, from http://www.bruno-latour.fr/sites/default/files/87-CONSTRUCTIVISM-GB.pdf

Lévi-Strauss, C., 1997, 'The culinary triangle' in C. Counihan (ed.), Food and culture: a reader, Routledge, New York.

Luhmann, N., 'Morality and the secrets of religion', in H. Vries (ed.), Religion and media, Stanford University Press, Stanford.

Numbers, R.L. [1976] 2008, Prophetess of health: a study of Ellen G. White, 3rd edn., William B. Eerdmans Publishing Company, Grand Rapids.

Ogden, J., 2010, The psychology of eating: from healthy to disordered behavior 2nd edn., Wiley-Blackwell, Chichester.

Pender, N.J., Murdaugh, C.L. \& Parsons, M.A., 2006, Health promotion in nursing practice, 7th edn. Pearson, Boston.

Pfandl, G., 2008, 'Foundations for Ellen White's prophetic call', Adventist World Magazine, viewed 22 May 2015, from http://www.adventistworld.org/2008/ Magazine, viewed 22 May 2015, from http://www.adventistworld.org/2008/
september/foundations-for-ellen-white-s-prophetic-call/1602-foundationsfor-ellen-white-s-prophetic-call.html

Pichon-Riviere, E., 1985, Teoría del vínculo, Nueva Visión, Buenos Aires, Argentina.

Review and Herald Publishing Association (ed.), 2000, Handbook of Seventh-day Adventist theology, Review \& Herald Publishing Association, Hagerstown.

Seventh-day Adventist Church ed., 2010, Seventh-day Adventist Church Manual, Revised 2010 18th edition, Review and Herald Publishing Association, Hagerstown.

Soler, J., 1979, 'The semiotics of food in the Bible', in R. Forster (ed.), Food and drink in history : selections from the Annales, économies, sociétes, civilisations, vol. 5, John Hopkins University Press, Baltimore.

Tambiah, S., 1985, Culture, thought, and social action: An anthropological perspective, Harvard University Press, Cambridge.

Turner, V., 1965, 'Ritual symbolism, morality and social structure among the Ndembu', in African systems of thought, Oxford University Press, London.

Turner, V., 1967, The forest of symbols aspects of Ndembu ritual, Cornell University Press, Ithaca.

White, E.G., 1945, 'Health', in Spiritual Gifts. Ellen G. White Estate, pp. 120-151, viewed 05 November 2015, from http://text.egwwritings.org/publication.php?pu btype=Book\&bookCode $=4$ aSG \& pagenumber $=120$

White, E.G., 1946, 'Counsels on diet and foods, table of contents - Ellen G. White writings', viewed 05 November 2015, from https://text.egwwritings.org/ publicationtoc. php?bookCode=CD\&lang=en

White, E.G., 1955, 'Divine guidance in the remnant of God's church, pp. 152-153 - Ellen G. White writings', viewed 22 May 2015, from http://egwtext.whiteestate.org/ publication.php?pubtype=Book\&bookCode=DGRGC\&lang=en\&collection=6\&sect ion=all\&pagenumber $=153$

White, E.G., 1997, 'Prophets and kings', page 714 - Ellen G. White writings, viewed 22 May 2015, from https://text.egwwritings.org/publication.php?pubtype=Book\&b ookCode $=$ PK\&lang $=$ en $\&$ collection $=2 \&$ section $=4 \&$ pagenumber $=714 \&$ QUERY $=$ But $\% 2 \mathrm{C}+$ thank+God $\% 2 \mathrm{C}+\mathrm{His}+\mathrm{church}+\mathrm{is}+$ no+longer+in+bondage.+To+spiritual+lsrae I+have+been+restored+the+privileges+accorded+the+people+of+God
me+of+their+deliverance+from+Babylon.\&resultld=1\&isLastResult=1

White, E.G., 1999, Colporteur ministry, page 125 - Ellen G. White writings', viewed 12 May 2015, http://text.egwwritings.org/publication.php?pubtype=Book\&bookCo de=CM\&pagenumber $=125$

White, E.G., 2002, 'Testimonies for the Church, vol. 6, page 327 - Ellen G. White writings', viewed 12 May 2015, from http://egwtext.whiteestate.org/publication. php pubtype $=$ Book\&bookCode $=6 \mathrm{~T} \&$ lang $=$ en \&pagenumber $=327 \& \mathrm{~m}=1$

White, E.G., 2006, 'Selected messages book 1, page 204 - Ellen G. White writings', viewed 22 May 2015, http://egwtext.whiteestate.org/publication.php? pubtype=Book\&bookCode=1SM\&lang=en \&pagenumber=204\&m=1\&paragraph References $=1$

Zito, A., 2008a, 'Culture', in D. Morgan (ed.), Religion, media and culture, Routledge, New York.

Zito, A., 2008b, 'Religion is media', viewed 06 November 2015, from http://therevealer. org/archives/2853 